\title{
THE SISTRUM AND THE \\ STICK RATTLES SABAYI AND SACHI
}

\author{
Long Fei [陇菲] \\ Contact: 290452737@qq.com
}

\begin{abstract}
This paper gives a brief outline of inherited links between various instruments. In doing so, attention is given to their spread and transformation process from an ancient Egyptian sistrum to a different type of a stick rattle ${ }^{1}$, also known as xi-stick or xízhàng in Chinese. This instrument once existed during the middle ages. In the process of time however, its use was witnessed in the Uyghur's' sabayi, the sachi and further to the Vietnamese sinh tien and the Japanese suzu.

These instruments can create a rapid succession of rattling and complex sounds, some of which simulating frogs croaking during tropical rainy seasons. Other sounds imitate the repeated thrum of rattlesnakes searching for a spouse. Depending on time and place, the former are linked with praying for rain and the latter with reproduction.

Thus, the rattles this study discusses are, among others, used in prayers for fertility and rain, peace and safety, healing rituals (curing diseases), for longevity. Furthermore, these rattles are sounded to ward off evil spirits, exorcise plagues and to keep poisonous animals away. All these resemble the mythological connotation to the copulating of Fuxi and Nuwa. Hence, they belong to the specific worldviews closely connected with the importance of reproduction in early times of humankind. They all involve fertility, death, reincarnation, eternal life, and the function of triggering trance, in which people seem to feel connected with heaven and earth, deities or ancestors.
\end{abstract}

\section{Keywords}

sistrum, stick rattle, sabayi, sachi, ritual use

\section{INTRODUCTION}

In this paper, I introduce some ideas regarding the stick rattle. In figure 1 , there is a long stick with a rotatable peach-shaped frame on top, made of a number of metal bars to which loosely fitted are six or twelve rings, making a specific sound like "xi" upon being shaken. Those types of instruments are seemingly common in images depicting Buddhist events as seen in an earlier publication Materials of Chinese Music History in Dunhuang Frescoes (Long Fei 陇菲, 1991: 446-450).

FIGURE 1: One shape of a stick rattle. (Photograph: Open access).

Here, I elaborate on the subject matter based on encyclopedic material that provided me with information about this historical period mentioning that the stick rattle is an instrument used in Buddhist

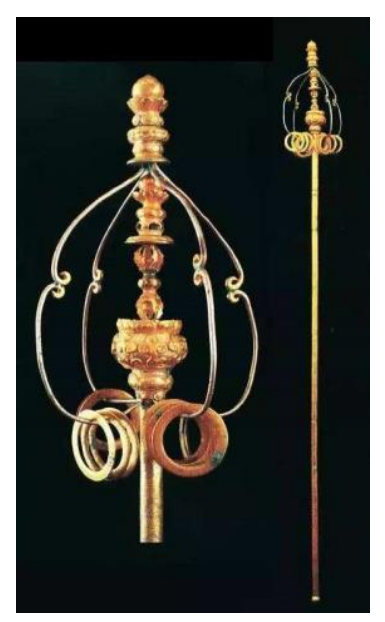
services, which was possibly transformed into sabayi of the Uyghurs and Uzbeks in the Islamized western regions after the $10^{\text {th }}$ century (Yuan Bingchang and Mao Jizeng, 1986: 274;

1 The term stick rattle is derived from the original meaning of xi-stick. Xi-stick is a transliteration of its Chinese name 锡杖 (xízhàng). If “xi” is absent, there is no possibility to discuss the similarities with a range of instruments of this type in pronunciation of names and its connection to an onomatopoetic appearance as suggested by the author. Yet, there is a need to clarify that all of these instruments are stick rattles of different length and shape, as well. The pronunciation will be, therefore, only discussed in the context of xízhàng. 
270). Similar instrument types are found under the names of syldyrmaq and asatayak among the Kazakhs, the bell ring and the triple ring among the Huis, the bell knife or halima-knife among the Manchus, and magic knife among the Zhuangs, Dongs, Yaos, Miaos, Tujias and Hans. The first syllable of sabayi or syldyrmaq sounds similar to that of $x i$, which has the meaning of 'rattling'. The stick rattle and those transformations are, so to say, related in form, structure, tuning and name.

What was Islamized in Xinjiang after the $10^{\text {th }}$ century was mainly connected to the religion and politics resulting out of this entire process. The musical culture of the local population was not completely interrupted during this period. Many musical instruments have crossed the fault line between Buddhist and Islamic constructions of civilization. The zhamunie, rewapu, daolangrewapu, rebabu, balangzikuomu, kumuriyi and kaomuzi may be mentioned as examples, showing obvious similarities with certain musical instruments of the Silk Road such as the qiuci-qinhan pipa. They use different names, but have similar features in form, structure, and tuning. These were most probably originating from musical instruments used by inhabitants along the Silk Road of those ancient times.

The discovery of the remains of the stick rattle xizhàng in the Islamized Xinjiang might be another substantial evidence of the historical fact that the musical life was not interrupted or completely changed. That is why I don't think Kishibe Shigeo's earlier claim that all the musical instruments of the ancient Silk Road have vanished (Kishibe Shigeo 岸邊成雄, 1973) is correct.

It has been nearly thirty years since I discussed the similarities between the Uyghurs' sabayi and the $x i$-stick rattle in terms of their form, shape, and structure, the correlation between their etymological designations, raising the question of how they crossed the obviously permeable fault line between Buddhist and Islamic civilizations in Central Asia and still maintained their unique form, feature and cultural connotations. Further studies conducted during these years revealed the inherited relationship between instruments of this type. In this conjunction, attention is given to the process of their spread and transformation from Egypt's sistrum to the stick rattle in the middle ages, the Uyghurs' sabayi and sachi further to the Vietnamese sinh tien and the Japanese suzu. Additional points worth examining referred to the historical thread that the first syllables of a range of similar rattles' terms show parallels to the name of a sistrum.

\section{LITERATURE REVIEW}

There are a number of short writings available about the sistrum. In addition, some pictures exist, all of them are mainly in the public domain. The literature mentioned here is selected since not all writings are accessible, neither physically nor virtually, or regarding their language. Therefore, this is just to introduce a small part of it, which the author finds important.

\section{SISTRUM}
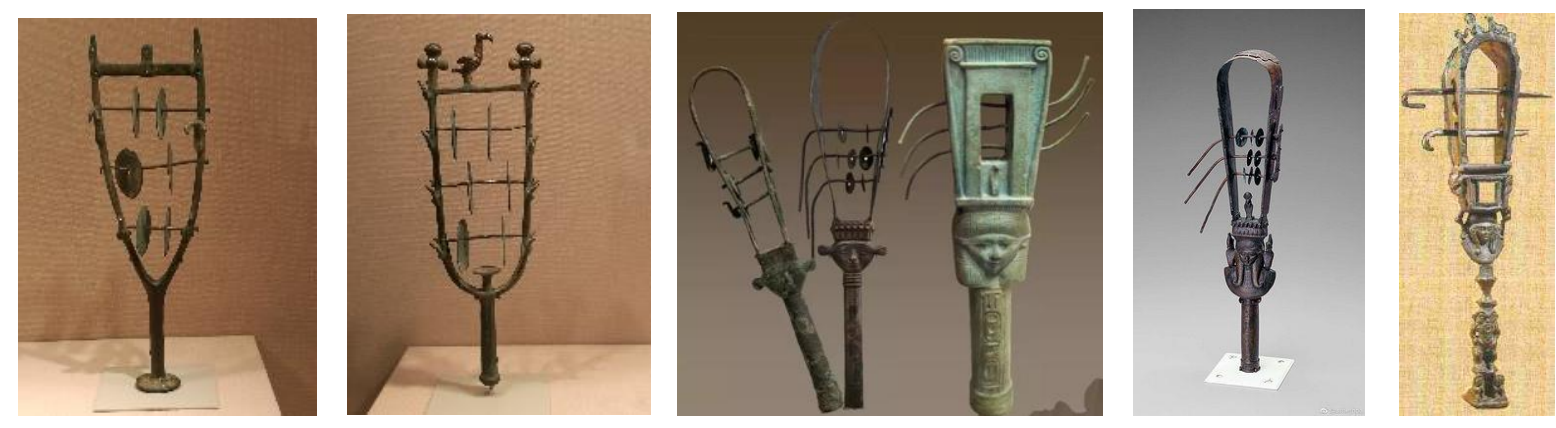

FIGURES 2-6: Ancient Egyptian sistrum in various depictions. The first two show examples collected in the New York Metropolitan Museum. (Photographs by Long Fei, 1 August, 2017). In the last three pictures an image of Isis' head is visible. (Open access, last retrieved 29 April 2020). 


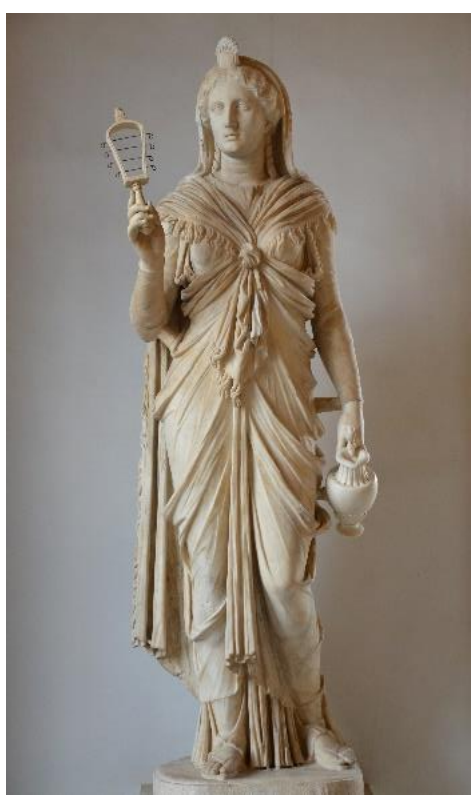

FIGURE 7: Roman statue of Isis, first or second century CE. She holds a sistrum and a pitcher of water, although these attributes were added in a seventeenth century renovation. (Photograph provided by courtesy of Carole Raddato: Marble statue of Isis, the goddess holds a situla and sistrum, ritual implements used in her worship, from 117 until 138 AD, found at Hadrian's Villa (Pantanello), Palazzo Nuovo, Capitoline Museums). ${ }^{2}$

Other encyclopedic literature is found in The New Grove Dictionary of Music and Musicians, in the Sage Encyclopedia Music \& Culture, and in some less prominent collections (Blade, 2005 [1970]; Powne, 1968; von Hornbostel \& Sachs, 1914; Yates, 1875). Single articles written about the sistrum come rather from younger authors, such as Timkehet Teffera who wrote in 2016 about the Ethiopian Sistrum Tsenatsil [ө่edd]. The evolving knowledge from all these writings can be supported with the examples presented in this paper.

The most elaborated and widely applied definition of the sistrum in the $20^{\text {th }}$ century is the following, which is partially taken from Encyclopedia Britannica and other works published in the 1990s and in later editions:

"Sistrum (Lat., from GK. seistron: "that which is shaken") is a type of rattle. Its shape was roughly that of a spur, consisting of a $U$ form with a straight handle protruding from the bottom. The $\mathrm{U}$ is transverse by loose-fitting metal rods, which jingle upon being shaken. Frequently small loose discs are fitted to these rods to create additional sound.

The sistrum was especially common in Egyptian cult music, at first in the worship services of Hathor and later in the worship services of her successor Isis. Its function here is usually interpreted as having been apotropaic, that is, as warding off unwanted evil spirits. Egyptologists trace its origin to black Africa where it still appears among certain tribes, as it does also among Coptic Christians. From Egypt, it spread to other Near Eastern civilizations, particularly the Sumerian. It was not at all prominent in Greece but was much used at Rome after Egypt became a Roman province in 30 BC. The cult was at first frowned upon officially but became established with the building of the temple of Isis under Caligula in AD 38. Roman representations of Isis generally showed the sistrum as one of her chief attributes."

FIGURE 8 (right): Egyptian Bronze sistrum, dated after $850 \mathrm{BC}$ (crossbars and jingles are added later); exhibited in the British Museum, London. Depicted in Encyclopedia Britannica (accessible via https://www. britannica.com/art/sistrum, last retrieved 16 April, 2020, courtesy of the trustees of the British Museum, London).

Shorter versions of this rather long definition can be found in a number of other encyclopedic works such as that edited by Ruth Midgley "Musical Instruments of the World" and some others. The pictures of this musical instrument can be found in many places. For example, as illustrations on other instruments such as on the front board of a lyre unearthed from a grave in Ur dating back to $2450 \mathrm{BC}$.

\footnotetext{
The figure places her weight on her left and moves her left slightly back and to the side. In her right hand she holds a small jug by her side (this object is the product of a restoration) and in her left a sistrum, a musical instrument. Originally an Egyptian goddess, the worship of Isis spread to the Greco-Roman world in the 4th century B.C. after the conquest of Alexander the Great over Egypt. Here the goddess is shown in a long chiton, a typical style of Greek dress. She also wears a mantle that ties over her breasts. A piece of the mantle is used as a veil to cover her head, which is also adorned with a sun disk. The work dates to the first century A.D. From Villa Adriana. capitolini.info/scu00744/. Public domain.
} 


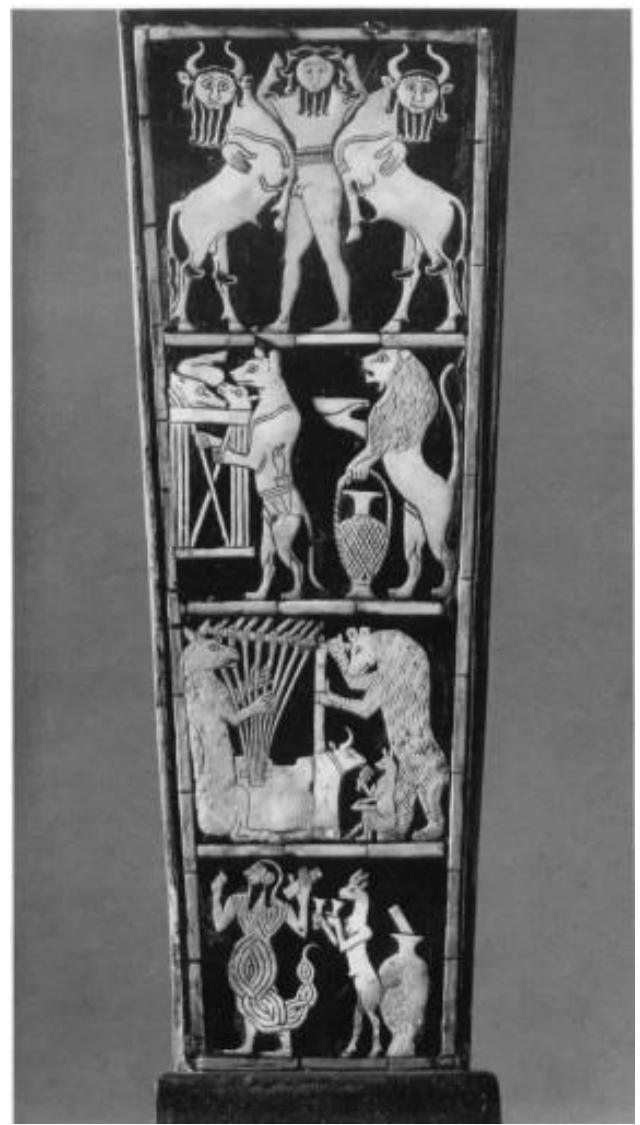

FIGURE 9 (left): The front board of the lyre unearthed from Ur Grave (Photography by VEB Deutscher Verlag für Musik, 1984; public domain; Subhi Anwar Rashid, 1984: 41).

\section{MesopotAMia}

The volume Mesopatamien (Mesopotamia) was written and compiled by Subhi Anwar Rashid and is a great source of knowledge in this regard. He explains the photo depicted in figure 10 with the following words: "On the third row, counted from the top, of this image [figure 10] is a donkey sitting and playing a large upright lyre, and a standing bear holding its cross rod and a vertical pole respectively with his front paw. The resonant box looks like the shape of a lying bull. A little fox or a jackal sits on the hind paws of the bear, holding a sistrum with one claw and beating something like a drum, a square one or a round one, with the other." (Subhi Anwar Rashid, 1984: 40).

In short: It is an image of an "animal band" on the front board of a lyre, unearthed from Ur Grave of the first dynasty of Ur Kingdom (about 2450 BC), which indicates that the Sumerians used the sistrum as early as that period.

As Martin Bernal (1987-2006) wrote in his Black Athena, "The Greek worship of Isis is a descendant of the Egyptian foundation established there 700 years ago." The ancient Egyptian worship of Isis had a great influence on that of Demeter in Eleusinian, Greece. Isis is considered as the archetype of Christian Virgin Mary. The earliest name of Paris was Perisis, meaning "the temple of Isis", according to the medieval literature accessible in the French National Library. The sistrum unearthed in Pompeji is a distinct proof that the ancient Egyptian civilization had a great impact on ancient Greek and Roman civilizations, which can be traced back to the Sumerian culture of Mesopotamia in 2450 BC.
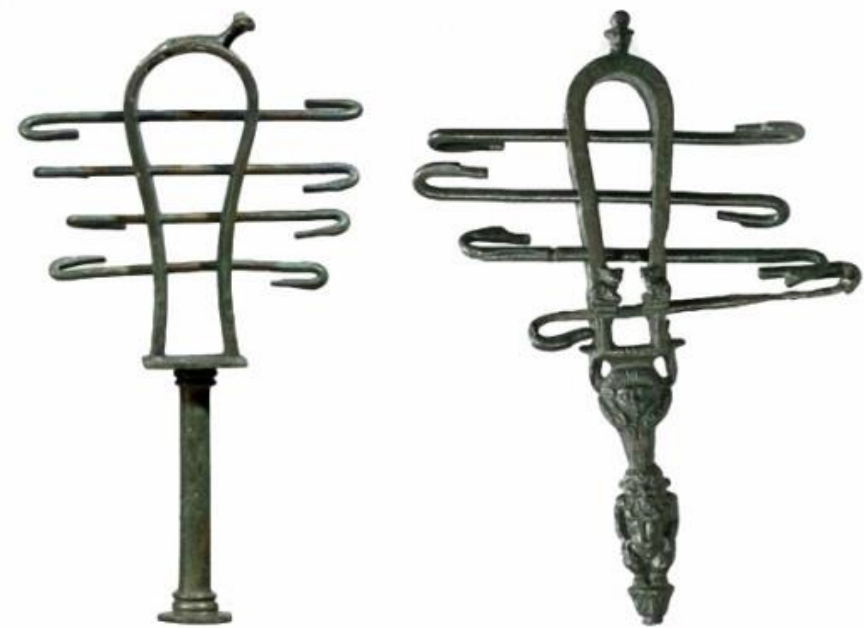

FIGURE 10-11: The sistrum unearthed in Pompeii in the $1^{\text {st }}$ century, Isis' image is visible on top of its handle in the second picture. (Photograph: Open access). 

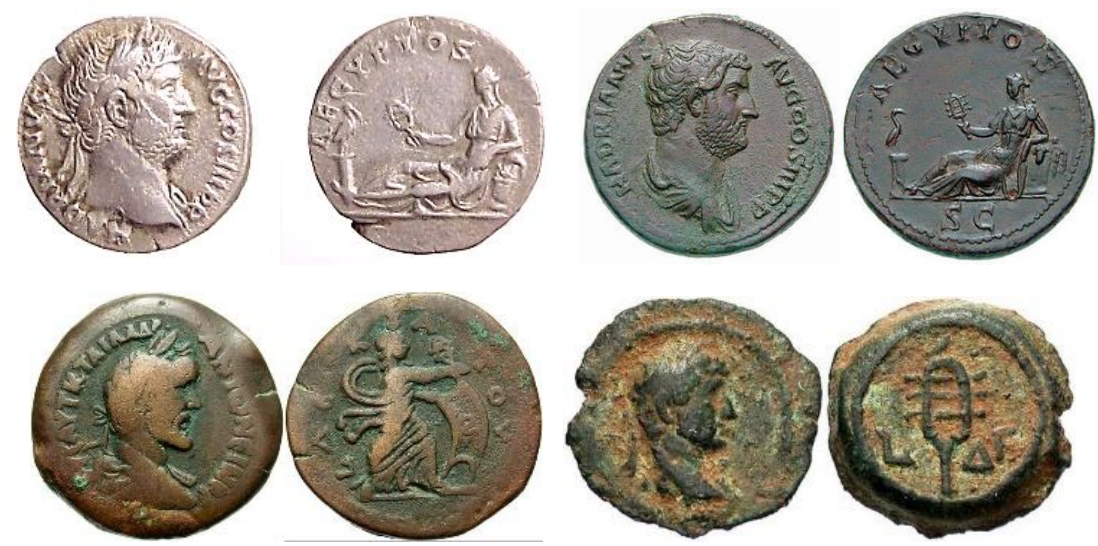

FIGURE 12: Various coins depicting sistra. (Photographs: Open access).

Images like these were also minted on coins in ancient Greece and Rome. Under the influence of Egypt's hierarchy, the worship of Isis appeared in these countries as well. So far, we have still seen the image of Isis holding a sistrum. It later became one of the motifs of Christian art. Sistra had a symbolic meaning in a number of paintings and pictures such as a fresco by Klimt from the $19^{\text {th }}$ century Vienna.
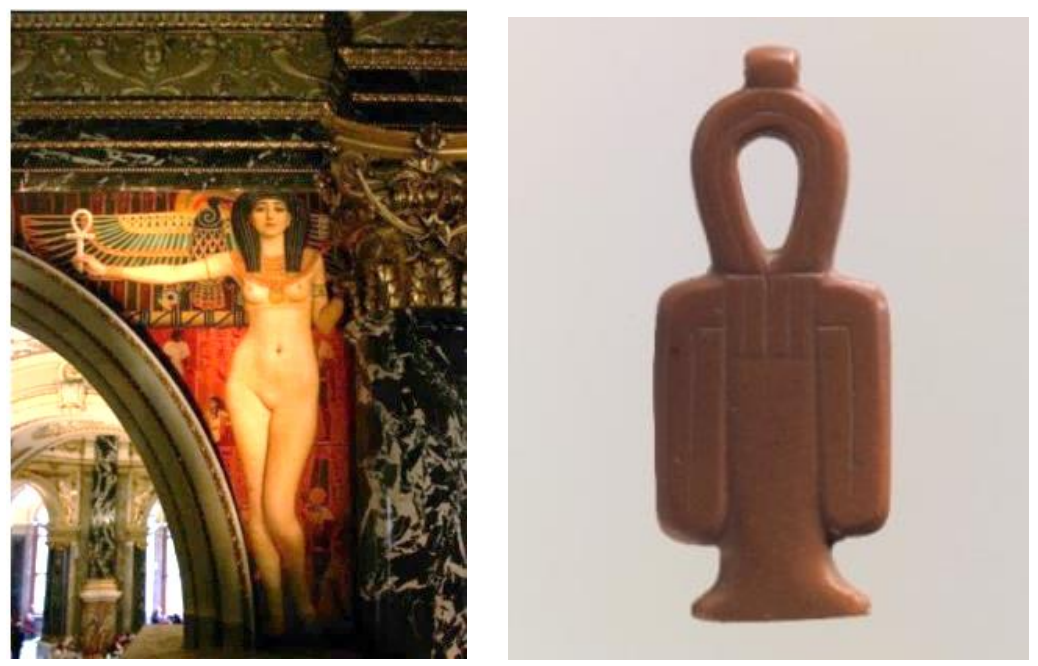

FIGURE 13: Fresco by Klimt in the $19^{\text {th }}$ century Vienna. (Photograph: courtesy of Chen Bohan); FIGURE 14: Egyptian amulet in the shape of an ankh, $2^{\text {nd }}-1^{\text {st }}$ BC. Others were called a tyet amulet that was used in the 15th or 14th century BC. The picture is accessible via the ancient world. tumblr.com. The figure 15 shows a tyet amulet, also known as Isis-knot. The photograph was donated to Wikimedia Commons as part of a project by the Metropolitan Museum of Art. (Photograph: Open access).
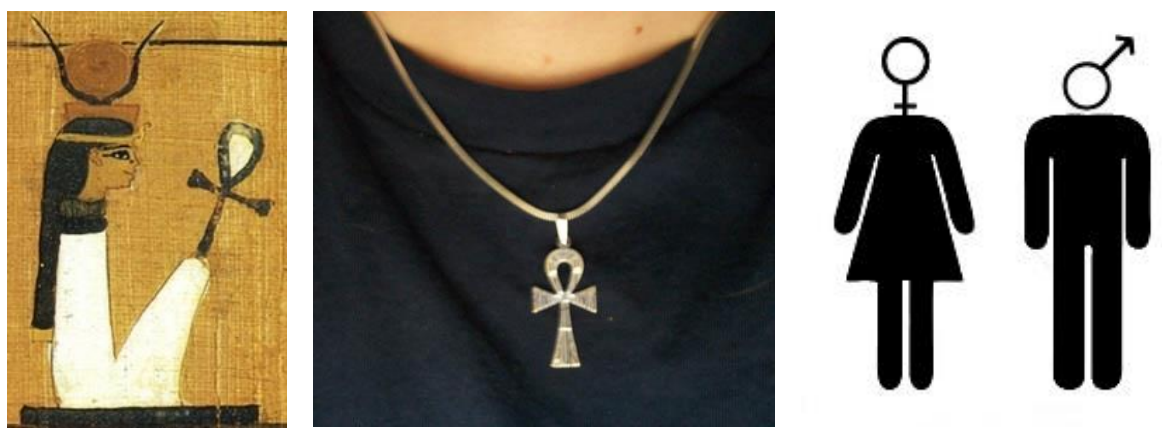

FIGURE 15-16: Ancient Egyptian sistrum with a cross handle; Figure 18: Stylized symbols for female and male. (All depictions are royalty free open access). 
Ancient Egyptian images often illustrate Egyptian king holding a sistrum in one hand and a scepter in the other. So does the queen, and the same God respectively holds both sistra (plural of sistrum) and scepter in both hands. In some images, they are combined to a whole sign consisting of a sacred charm.
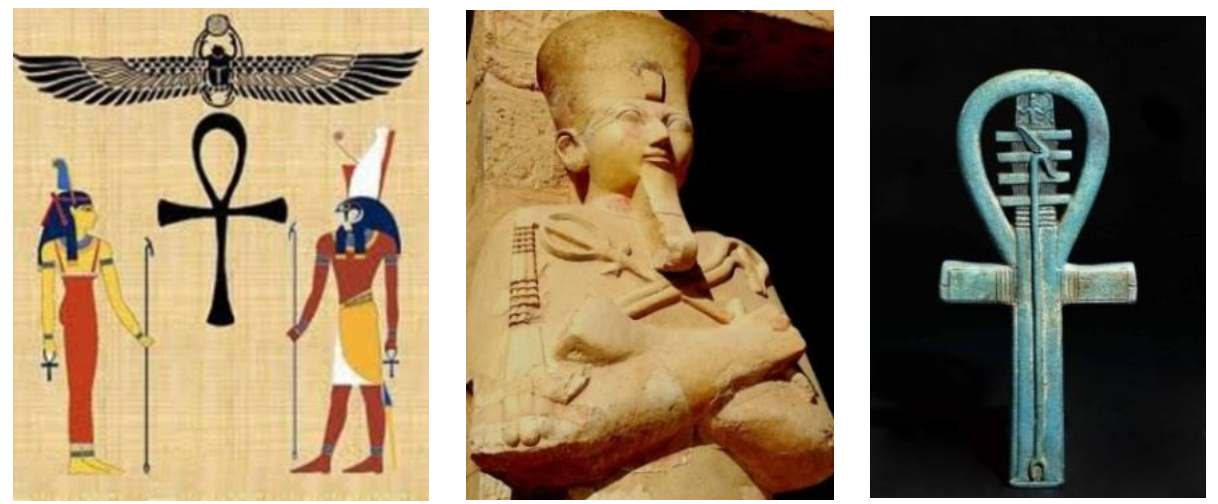

FIGURES 17-19: Egyptian king and queen hold the sistrum and scepter in the $1^{\text {st }}$ picture. A god holds the same things in his hands in the second; Figure 21: The sistrum and scepter are combined into a whole sign, the background of which is the sistrum and the scepter in the middle. (All depictions are royalty free open access).

\section{SPECIFIC CHRISTIANITY}

The bronze sistrum that was a type of percussion instrument, common in Egypt during the $9^{\text {th }}$ century BC, remained in use along with other musical instruments within the Ethiopian Orthodox Church use to accompany the religious chants for centuries (Teffera, 2016).

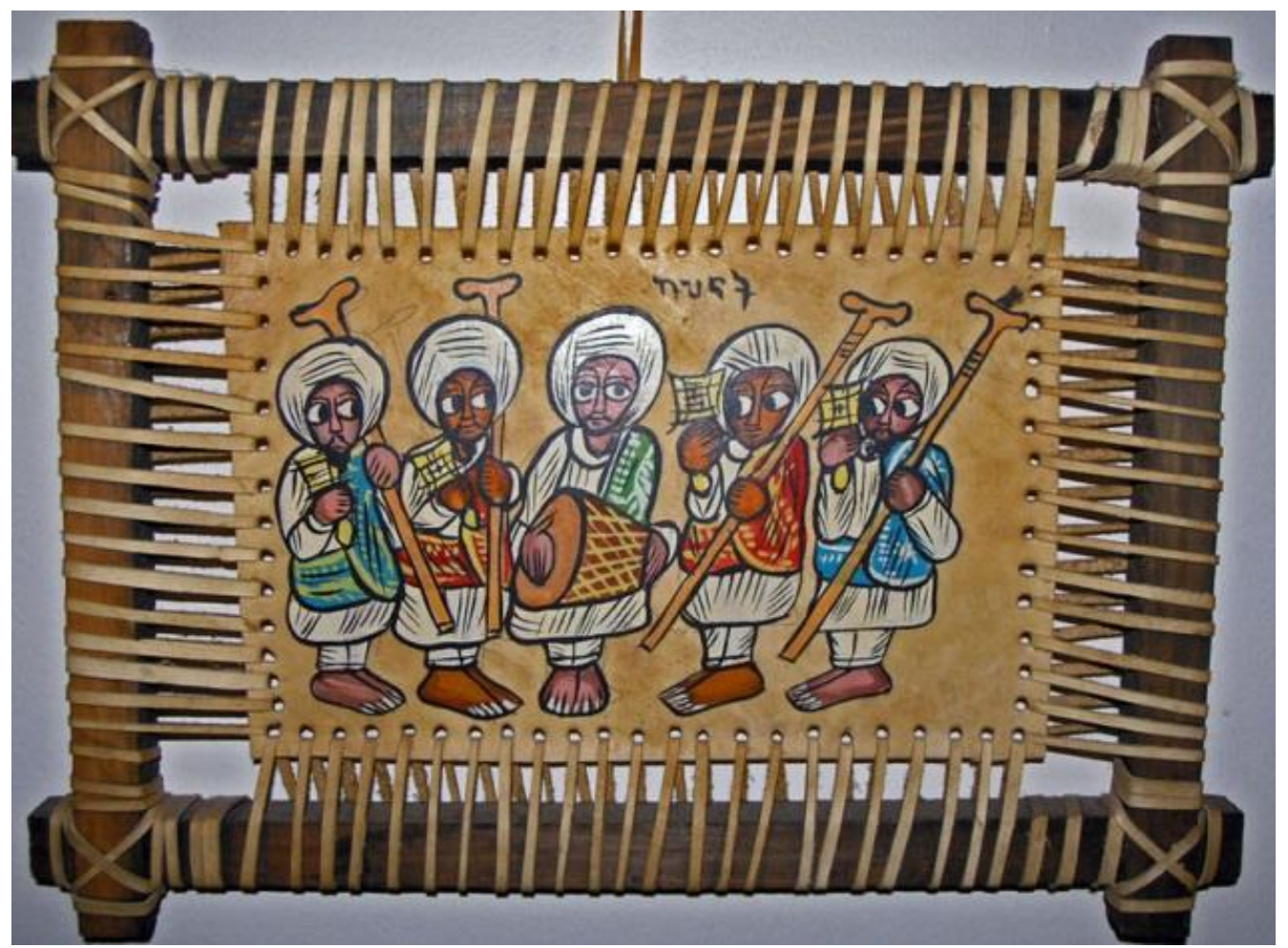

FIGURE 20: Photography of an Ethiopian painting by Jahsensie taken on 10 June, 2005. "Peinture éthiopienne sur cuir représentant des prêtres éthiopiens jouant du sistre et du tambour." (Open access).

Four musicians, two of them each positioned at the drummer's side, in this image, hold a prayer stick in one hand and shake a sistrum they hold in the other hand. This resembles Egyptian 
depictions. The prayer stick is a type of scepter rather than a musical instrument that can be used for structured playing. Probably, the prayer stick and sistrum were later combined into a stick rattle.

In the Metropolitan Museum of New York, there is a long-handled rattle from Rajasthan, India, which is a type of stick rattle.
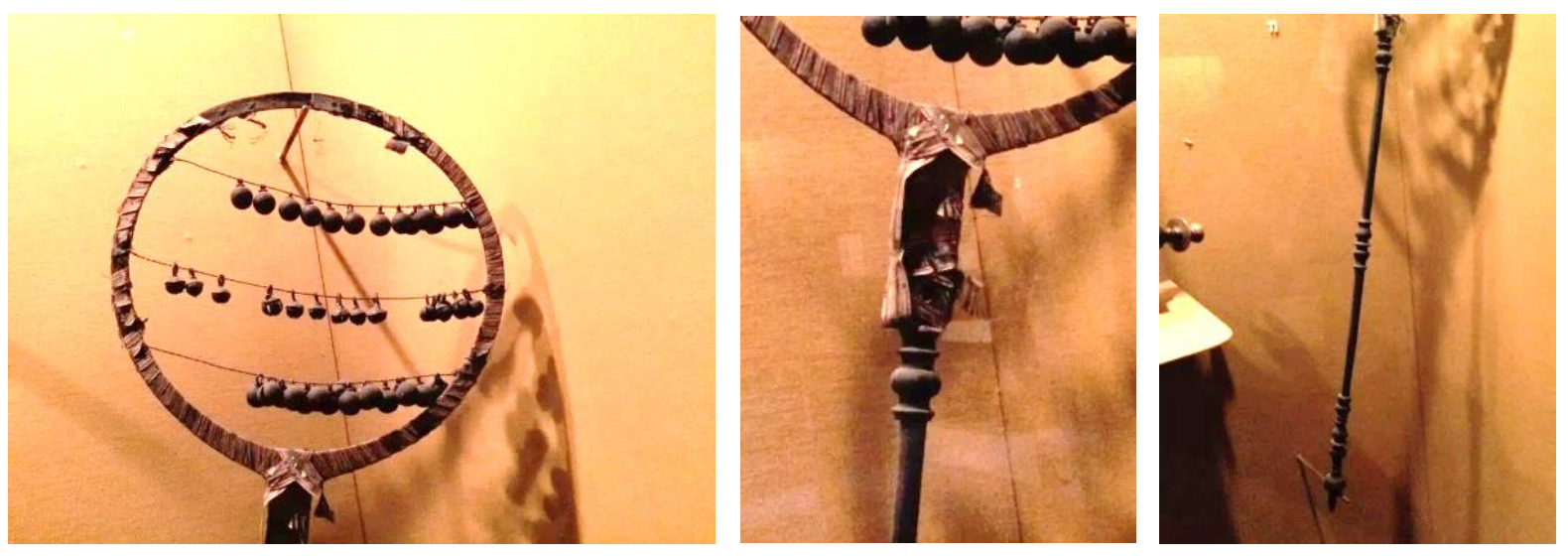

FIGURES 21-23: The rattle with a long handle, India, unknown time period. (Photographs courtesy of Xiao Mei, taken in the Metropolitan Museum of Art, New York, 2015).

Some scholars point out that this instrument can be used to be catapulted into "trance" state, a psychological state, in which the magician, the sorcerer, or the shaman himself seems to feel " connected with heaven and earth" and "staying in the world of deities" (Blade, 2005; Sachs, 2006). It is rendered as "gods descending to the world" or "gods coming down to earth" in some Chinese ritual practices. Xiao Mei (2016) translated "trance" into 转思 [zhuăn sī] in Chinese, i.e., with the idea of changing, in order to fit both its sound and meaning, which entails entering into another state of mind. The sistrum, sabayi or similar musical instruments can also help to trigger trance as any other hallucinogenic drugs do.

Moreover, there is another type of rattle with a long handle, used in pairs in the Syrian Orthodox church located in the Martin Province in Turkey, as I was informally, told. It looks like an intermediate form between a sistrum and a stick rattle, similar to another a specimen found in The Metropolitan Museum of Art, in India.
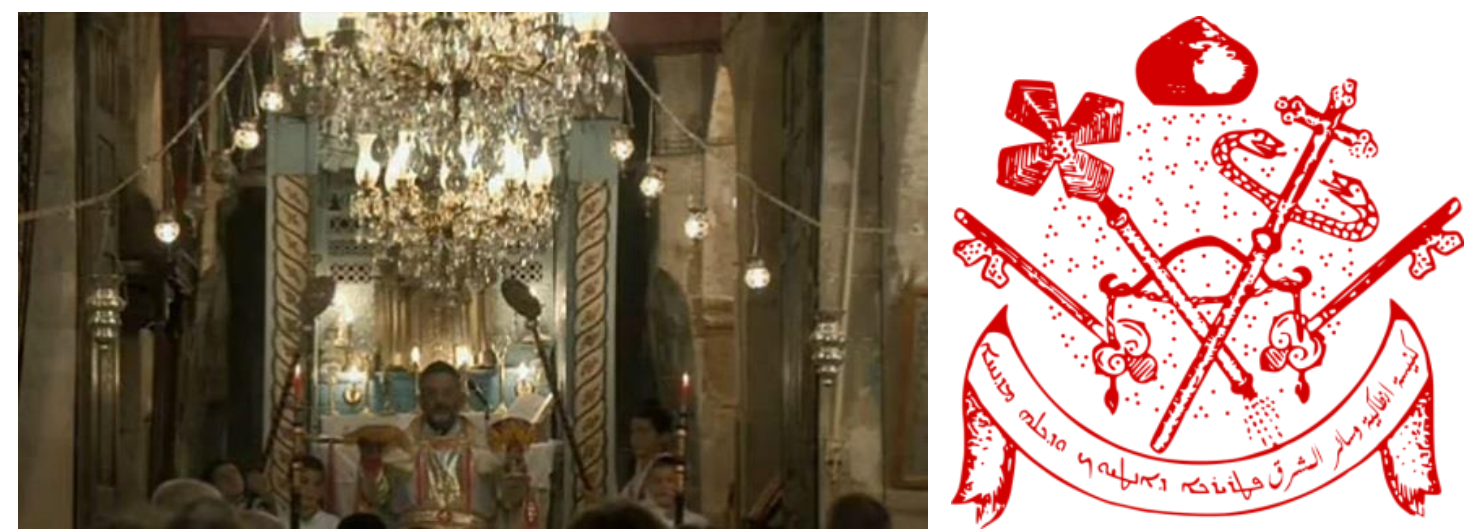

FIGURE 24: Turkish rattle with a long handle used in pairs. (Screenshot by Long Fei taken from a local documentary in 2010); Figure 23: The Logo of the Syriac Orthodox Church. Visible are various sticks that can carry small rattle elements. Openly accessible via https://www. wikiwand.com/en/Syriac_Orthodox Church. Reproduced on 10 November, 2018. 


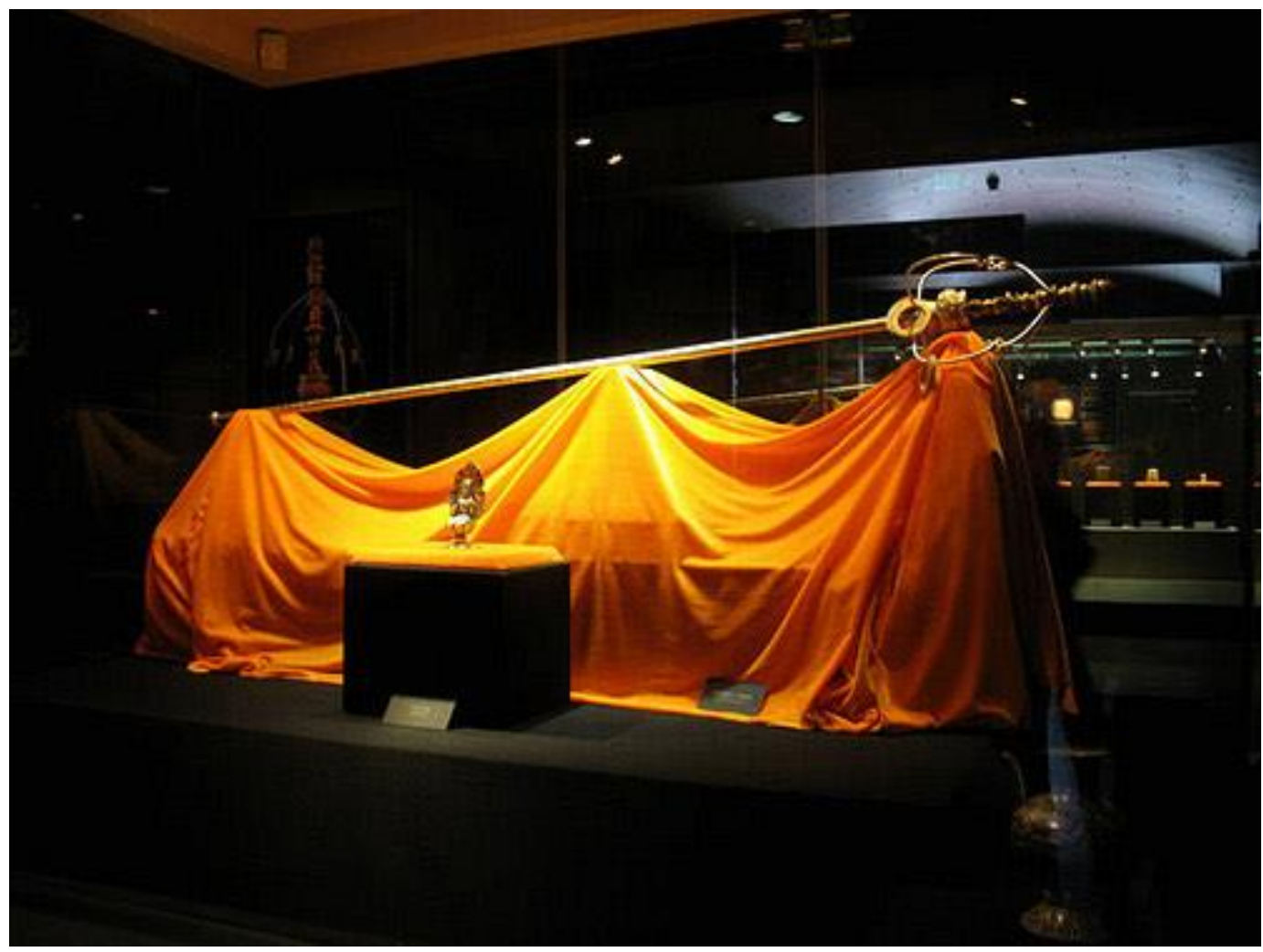

FIGURE 25: The stick rattle xízhàng unearthed at the Famen Temple near Xi'an exhibited in the temple's treasure hall, 2018. (Photography open access).

In the Dictionary of Buddhism (Ding Fubao 1987) one finds a description of names for this stick rattle as following:

"Stick rattle (xízhàng): Khakkhara (in Sanskrit), one of the eighteen instruments used in Buddhist services. It is called xi-stick, sheng-stick meaning sound stick or ming-stick in Chinese. The rattling sound of the stick rattle is caused through being shaken. It is also named zhi-stick (wisdom stick) or de-stick (morality stick)."

Khakkhara is transliterated into kaiqilo, chiqilo or xiqilo in Chinese, each of which sounding like sistrum in Sanskrit. In the following, some sutras are roughly interpreted. Although they are published in several literatures, yet it is impossible to give a specific source of citation. Sutras are well-known short episodes or teaching (pedagogical) stories found in popular books about Buddhism. The main ideas are summarized in English as follows:

\section{The Dedaotideng Sutra of the stick rattle (xíhàng)}

Buddha says to a monk, "You ought to accept the stick rattle when it is given to you. The reason is that each Buddha--- either the past, the present or the future --- has one. It is also rendered as $z h i$-stick (wisdom stick) for publicizing the wisdom of Buddhism, and as de-stick (morality stick) for doing boundless beneficence. It is the mark of the saint, the sign of the sage and the image of Dharma.

\section{Sutra of Jizo Bodhisattva (Ksitigarbha) - 2}

Good deeds come from benevolence. Vows are for saving all human beings. The golden stick rattle in the hand can open the gate of hell, the bright pearl in the hand can illuminate the entire universe. In the wisdom sound and auspicious clouds, do immeasurable indisputable merits and virtues for the suffering people in the world. Cherish great mercy and great wishes, and great holiness and great kindness. 


\section{The Picture Story of Mulian Saving Mother in Hades, Vol. 1}

Buddha says: "I will give you my $x i$-stick rattle in case of emergency. It can be used to drive out varieties of disasters and difficulties for you. The gate of hell should be opened so long as ye repeat my name continuously."...King of Jizo asks: "Why did you open the gate?" Mulian replies: "Who else could have done that except me? Buddha has given me something for that." The king asks again: "What's that?" The answer is: "It is a stick rattle with twelve rings."

\section{Shisonglv (Sarvastivada-vinaya)}

What the stick rattle's mana is, Buddha stays in the cold woods, where poisonous snakes have appeared frequently and bitten the monks. Buddha says: "You should make a stick to create sound, which can drive them away." That is named magic stick.

\section{Sifenlv (Dharmagupta Vinaya)}

Walking along the road, several monks see snakes, maggots and centipedes around. Frightened, they tell Buddha about it. He replies: "Drive them away by shaking $x i$-stick rattle to create sound."

\section{Petunia Chores}

To beg for food, a Buddhist monk knocks at a door with his fist and the family in the house is disturbed and then complains: "What did ye want to do?" Silent, the monk has nothing to say. Buddha says: "You shouldn't have done that but make a xi-stick rattle." The monk does not understand, then Buddha explains: "Fasten a ring as round as a dish to the top of a stick and fit to it a number of small loose rings. Shake it to create sound and that will call them out."

...Once at an unbeliever's gate, he shakes his $x i$-stick rattle so many times that he feels tired, still nobody comes out and answers him. Buddha says: "You shouldn't have done that so long but twice or thrice, then leave there if nobody answers."

\section{Fundamental Chores}

To beg for food, a Buddhist monk enters into an elder's house and then he is ridiculed and slandered by that family. Buddha says: "Make something to create sound to make them hear." Then he makes a stick rattle.
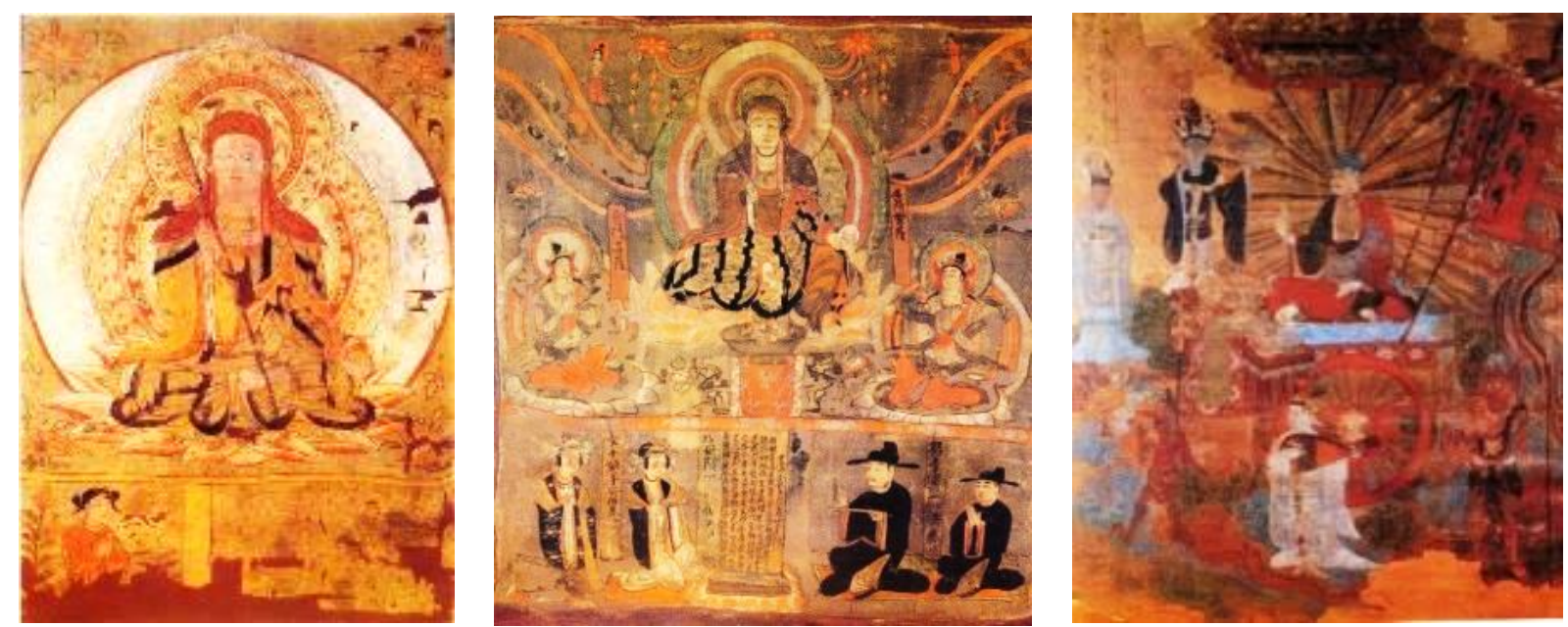

FIGURE 26-28: In the first two pictures, King of Jizo holds a stick rattle over his right shoulder. In the third, Tejaprabha Buddha has a stick rattle in his hand. Katharine Schlesinger (1921) calls the stick rattle in this picture just sistrum in her Annotations to Musical Instruments in the Stein Collection. Public domain.

The Buddhist monk's traveling around with a stick rattle is known as flying-xi or patrolling- $x i$ and his staying somewhere as hanging- $x i$ or staying- $x i$. For the convenience of those who travel across the desert, carrying only a bowl and a stick rattle with them, a type of small stick rattle has emerged, which seems to be what is between the stick rattle and sabayi. 


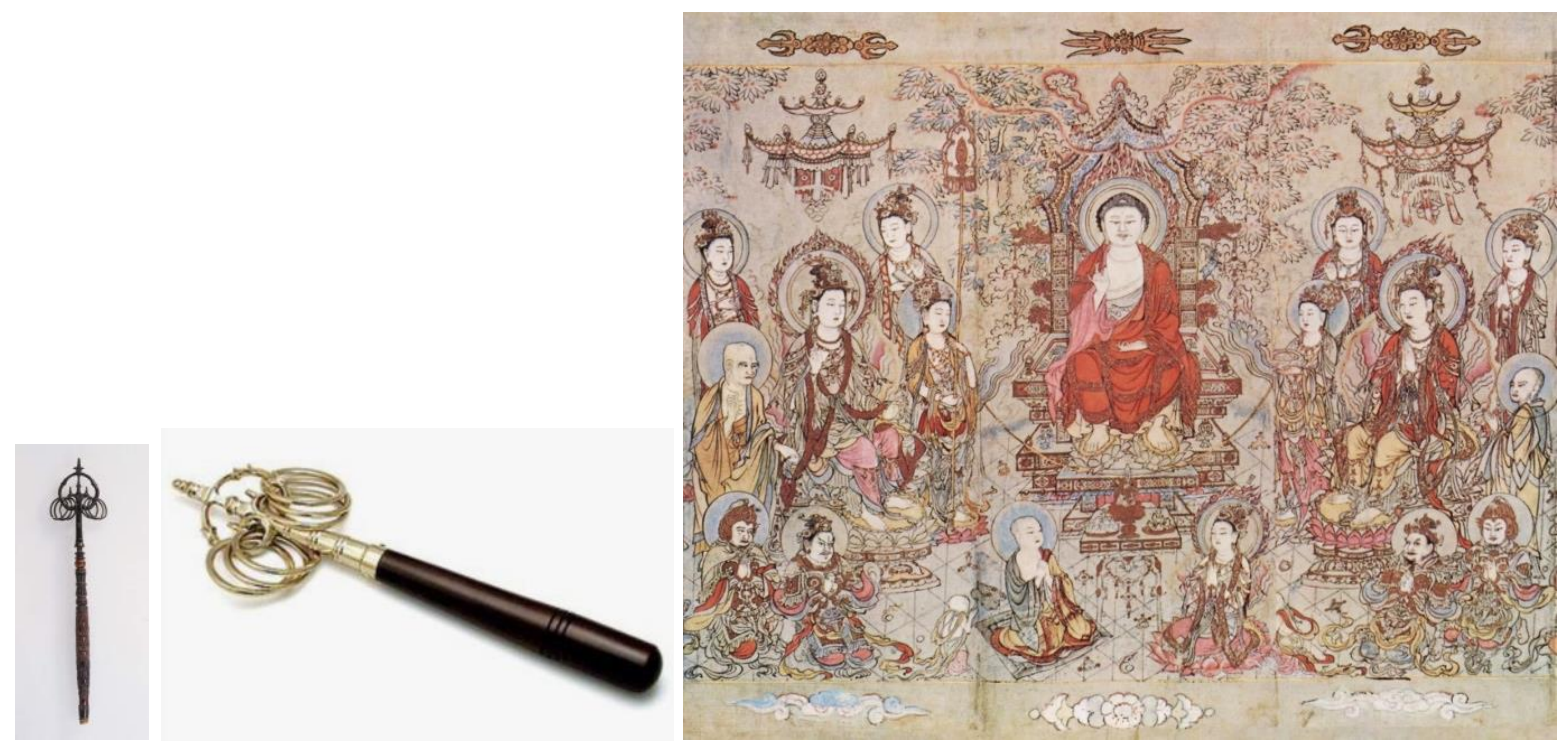

FIGURE 29: A shorter traditional stick rattle (Photography by courtesy of Akiko Ban); FIGURE 30: A modern stick rattle distributed via online shops (accessible via【楽天市場】【密教法具寺院用仏具】鳴 金錫杖(真鍮柄) 小型 長さ $25 \mathrm{~cm}$ 【お盆用品 仏具 お彼岸 寺院仏具 京都製 国産品 通販 楽天】: 仏壇屋 滝田商店. Last retrieved 1 May, 2020; FIGURE 31: Buddha's teaching. A long stick rattle is seen on the left of his seat hold by a close follower. Accessible via https://culture.followcn.com/2017/01/10/influence-ofbuddhism-in-ancient-chinese-arts/, last retrieved 1 May, 2020.
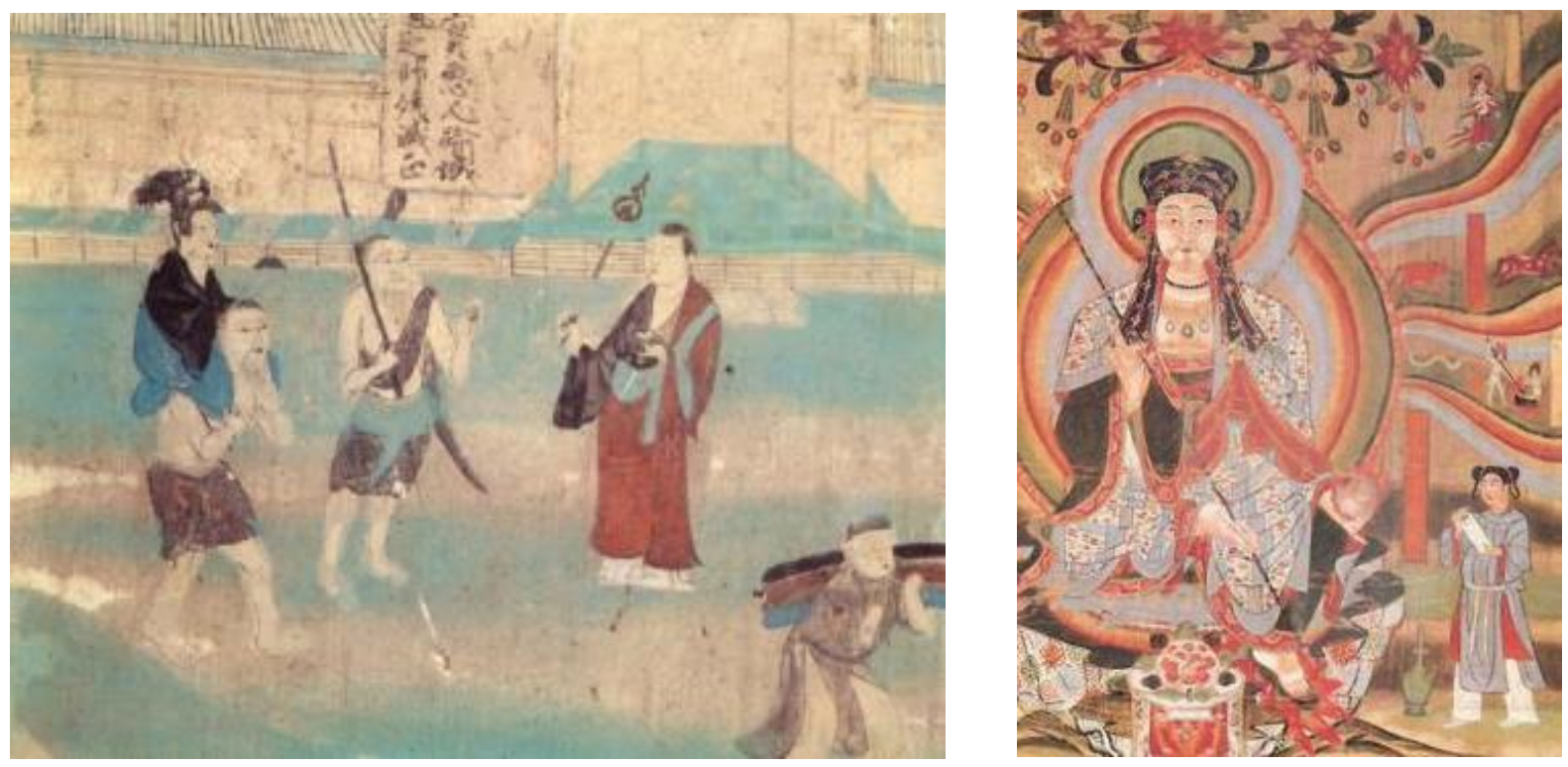

FIGURE 32: A'nan begs for Alms with a small stick rattle and a bowl in his hands. This picture is on the east side of the southern wall of the main room, No.85in the Mogao Cave, and it was drawn possibly during the Late Tang Dynasty (photography by the author); FIGURE 33: Buddhist teaching. The main figure is holding a stick rattle in the right hand. Accessible via https://www.kunst-fuer-alle.de/media_kunst/ img/36/g/36_157742 chinesische-malerei_budd-hist-banner-depicting-dizang-and-the-six-roads-torebirth-from-dunhuang.jpg, last retrieved 1 May, 2020.

\section{The Dictionary of Buddhist Light}

The small stick rattle is quite similar to the Chinese Uyghurs' sabayi in form and structure. The Japanese Buddhists of Tiantai and Zhenyan sects would be shaking it while chanting in their Buddhist services. This is one of the four elements of important Buddhist rituals. What they are chanting on such an occasion is called xízhàng specially. 
There is a similar instrument suzu, also known as the witch bell, i.e. 神楽すず in Japan.

FIGURE 34: Suzu, exhibited in Peter the Great Museum of Anthropology and Ethnology in St. Petersburg. (Photography by courtesy of Liu Guiteng, St. Petersburg, 2019.)

Some important information is contributed to the Dictionary of Chinese Music (1984). Here, we find the following description:

"Sabayi is a type of rattle of the Chinese Uyghurs in various shapes. Originally, it consisted of a pair of ram horns with a number of loosefitting iron rings. Nowadays, it is made up of two pieces of side-byside positioned hardwood sticks, fastened to each other in the middle, where two big iron are rings with a number of loose-fitting small iron rings. In a performance, the player holds it with the right hand, shaking it or hitting it against the shoulders or the other hand to create sound. Usually it is operated as the musical accompaniment to

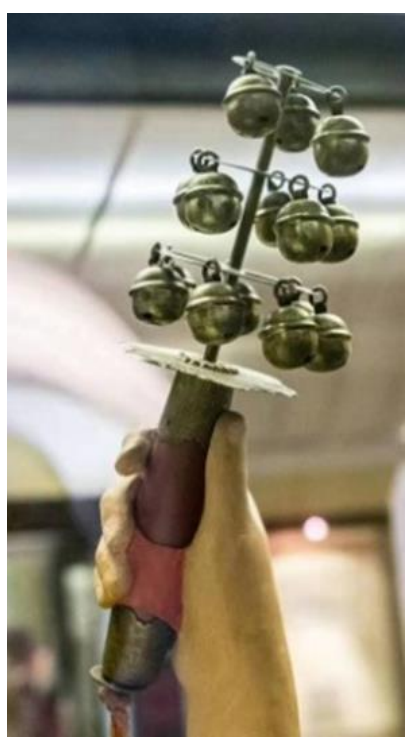
dances.”

In Wan Tongshu's work (1986) “The Musical Instruments of the Uyghur”, there is a short introduction referring to sabayi. It is written that in the past, some people, who were suffering in life and extremely disgusted with the world, used to be wandering about, hair scattered, in graveyards or wastelands, singing songs and shaking sabayi in order to give vent to their sorrow and anger. Beggars would shake sabayi in accompaniment to chanting maqamat, begging for alms at the roadside. In addition, it was one of the instruments, the Bakshi used to drive evil spirits out of patients.
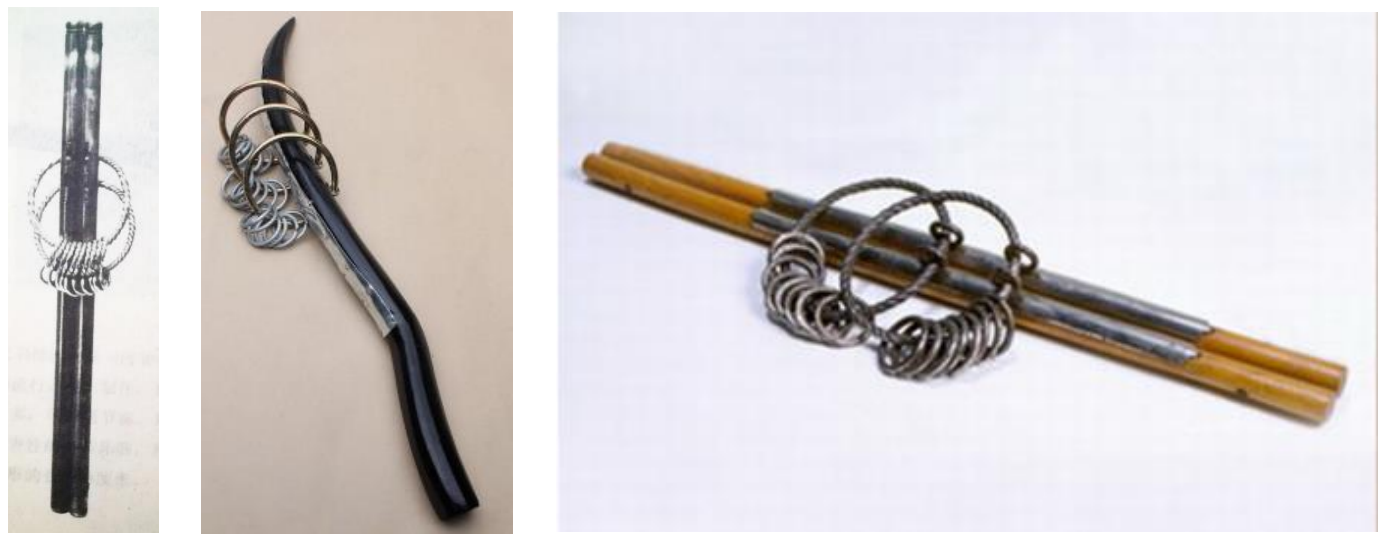

FIGURE 35-37: Different shapes of sabayi and people shake it, chanting along (All photographs open access, Figure 35 as depicted in "The Chinese Musical Instrument Atlas" (1987: 196).

These should be successors of the Buddhist monk incognito, staying marginalized in the Islamized Western Regions. What they did for begging was entirely in the style of the previous Buddhists. Bakshi exorcises evil spirits with sabayi as Buddhists do it with the stick rattle. They have the same religious connotation.

Bakshi, also known as ashiq, is classified to the Sufi of Islam. In fact, what some Uyghurs have actually adopted is a custom that may have its roots in Buddhist rather than their Shamanist traditions. However, there are other kinds of use of the sabayi-type among male Muslim pilgrims, evident in performance practices of South and Southeast Asia such as Dabus.

An ashiq is also known as keletair, meaning the beggar, of whom the one with high accomplishment in Buddhist knowledge and practice is known as Dervish. The wandering 
Buddhist monk is also called Dervish, who travels out begging for alms, in the robe of patches, with a $x i$-stick rattle or a Jingang pestle in one hand and a bowl in the other. These two kinds of Dervish have the same connotation in culture.

The original stupa was a Buddhist shrine dedicated to the storage of the eminent monk's relic while Mazar Ashq worships is the holy land or the Holy sepulchre. They both contain the same cultural connotation. The Islamic holy land is usually the ancient Buddhist shrine in Xinjiang. The tradition of prayer flags hanging up over Tibetan Buddhist cairns seems to remain on some Mazars in the fields.

The worship of Mazar differs from the Islam's five-time-a-day- lesson and is more like going to the Buddhist temple fair. Some Mazars are in memory of those who could enable infertile women to have children and some others of those who could exorcise evil spirits and cure diseases. They both are similar to the Buddhist worship of Herbalist Buddha (Bhaisajyaguru) and King of Jizo (Ksitigarbha).

The Records of the Barbarian States in the Western Regions (according to the annotator Zhōu Liánkuān, $2000^{3}$ )

Some people have abandoned their families and disregarded their businesses. Away from normal life, they are unkempt and barefoot, in tatters or sheepskin, holding a strange stick, wearing a chain of bones of ox or sheep, looking extremely weird. They have been walking all the way begging for alms in cold and hot weather, and would be muttering something when meeting with people, showing how pitiful they are as if life was so hard for them to survive. They would gather at the cemetery and live in caves, claiming and doing ascetic practices. This is called Dilimishi. In order to free oneself from the pain of the soul.

"Dilimishi should be Tilmidh in Arabic, which is what the authentic Buddhist called the heretic believer originally. The latter willingly endures physical pain, living an ascetic life so as to liberate himself from the pain of spirit." (Zhōngwài jiāotōng shǐjí cóngkān běn, 2000: 87). Zhōu Liánkuān wrote this in his Annotations to the "Records" mentioned above and created by Chen Cheng and Li Si in the Ming Dynasty and printed publicly in 1991. The cemetery here should refer to Mazar. All these are deeply ingrained within the Buddhist civilization.

It is still unknown whether this strange stick is a stick rattle xizhàng in a changed shape. Maybe, it is a transitional form between stick rattle xízhàng and the sabayi.

The stick rattle was a fashionable instrument while Buddhist civilization flourished in ancient Western Regions, but it had to go incognito after the introduction of Islam in the $10^{\text {th }}$ century. In this situation, the small $x i$-stick rattle continued to be popular among the people in the name of sabayi. It does not appear to be fortuitous that the first syllable of its name sounds similar to that of a sistrum or a $x i$-stick rattle. That is the reason why the $x i$-stick rattle has transformed into sabayi.

\section{Grand Exposition of Chinese Music Culture (2001, Beijing)}

Syldyrmaq is a type of percussion idiophone of the Kazakh people. Its name is transliterated from Kazakh, meaning voice of owls, consisting of a piece of wooden board with six strings of

\footnotetext{
3 Zhou Liankuan (10 February, 1905 -17 December 1998) is a library scientist, bibliographer, archivist, historical geographer, one of the professors and founder of the Information Management Department at Sun Yat-sen University. Formerly known as Zhou Zixian and Zhou Zhao (aliases: Kuzhuzhaizhu, Dugong, Kuany). He graduated from Wuchang Wenhua Library College in 1930 and later became director of the Shanghai Municipal Library, professor at Sun Yat-sen University, at the Department of Library Science. He annotated and proofread 陈诚、李暹（著），周连宽（校. 1991 年，《西域行程记·西域番国志》（中外交通史从书），北京：中华书局 in the year 2000 .
} 
metal discs fastened on it and some owl feathers fixed to the upper end of the board as an ornament. During the performance, the player holds its handle, shaking it to create sound in the rhythm of the music. It is used as the musical accompaniment to singing and dancing for entertainment, common in Northern Xinjiang.

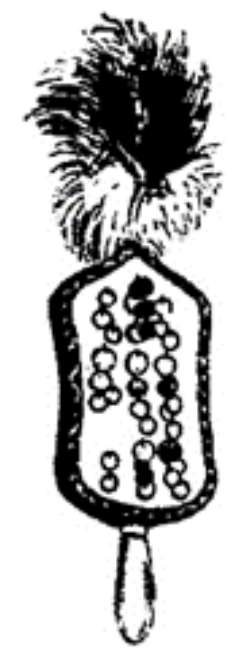

FIGURE 38: Syldyrmaq (source provided by the author: Great Dictionary of Chinese Musical Instruments. 2002. Beijing: Yue Sheng: 610).

It does not seem incidental that its first syllable sounds similar to that of the sistrum or the $x i$ stick rattle, for they are similar in form, structure and function. Classified finely by the way of playing, syldyrmaq should belong to a rattle type rather than a percussion instrument because it is shaken not struck.
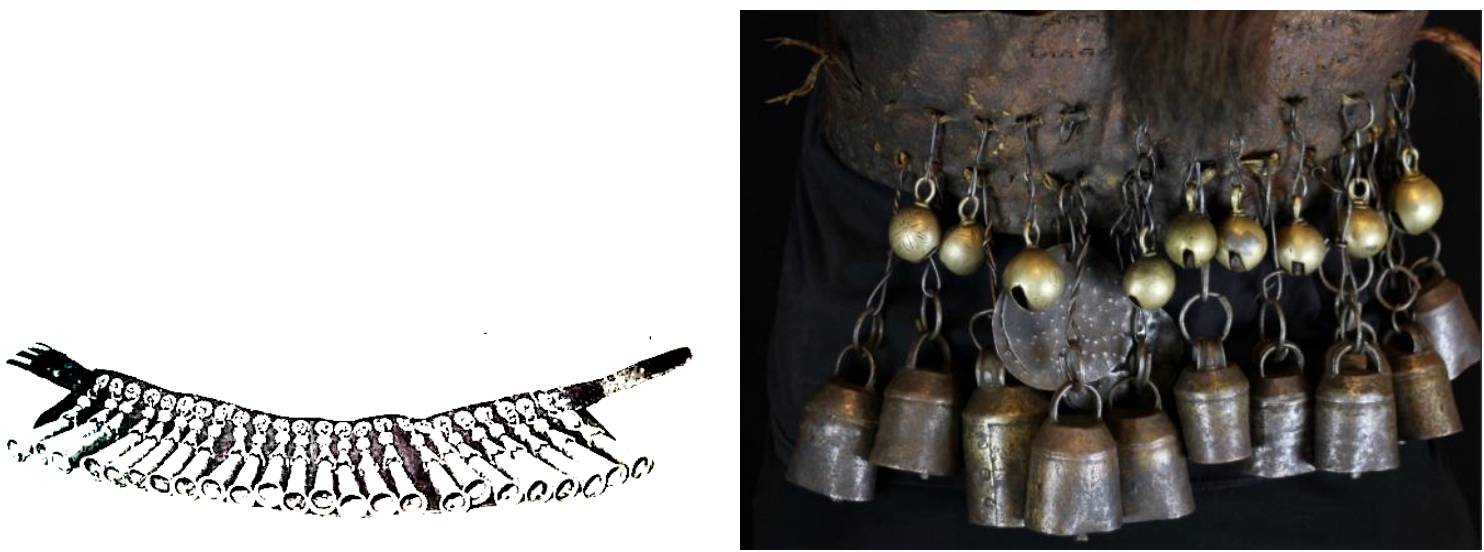

FIGURE 39: Xisa: An apron belt depicted in "The Chinese Musical Instrument Atlas" (1987: 186); FIGURE 40: An apron belt with rattle elements and small bells as found in Nepal among shamans. (Photography by courtesy of David Alan, accessible via https://thedavidalancollection.com/ 2018/08/08/musical-instruments-from-japan-indonesia-nepal-sacred-secular-and-unusual-pieces/, last accessed 1 May, 2020).

Another information features Yue Sheng's work (1988) titled "The Musical Instruments of the Minorities in China". For example, He suggests the following: Xisa is a type of percussion instrument, which is also known as waist bell and called shaman bell in Manchu language, used by the Manchus, Hans, Daurs and Ewenkis, common in such parts of China as Liaoning, Jilin, Heilongjiang and the eastern Inner Mongolia Autonomous Region. Made of copper, iron or alloys, it consists of thirty-two small trumpets and three small bells, fixed alternately on a piece of ox hide or horsehide, $50 \mathrm{~cm}$ long and $20 \mathrm{~cm}$ wide. Each trumpet, $15 \mathrm{~cm}$ long, with the upper diam. $2.5 \mathrm{~cm}$ and the lower, $4 \mathrm{~cm}$, has a small ring fixed to its tip. All of these rattle vessels are fastened on the rear of a belt made of ox hide with $120 \mathrm{~cm}$ length and $7 \mathrm{~cm}$ width. The whole 
stuff weighs more than $15 \mathrm{~kg}$. The trumpets and bells create sound when waved, swung, paused, swayed or shaken, mostly used together with other instruments in the performance...much used by the Daurs, Mongolians and Hans in the cult, exorcism and other services.

Xisa is different from the sistrum, stick rattle, or sabayi through its form and structure but its function has striking similarities with the two music instruments. It does not seem unexpected that the former's first syllable sounds similar to the latter. Since it is finely classified through its way of playing, xisa is undoubtedly a rattle.

\section{The Dictionary of Chinese Musical Instruments (1999, Beijing)}

Magic knife is a type of rattle idiophone used by the Manchus, Zhuangs, Miaos, Yaos, Dongs, Tujias and Hans, called hama-knife or bell knife in Manchu language and saman knife in Northeast China. Made of copper or iron, generally it consists of a pair of scissors with a number of small loose iron bells fitted to the handles, common in such regions as Liaoning, Jilin, Heilongjiang, Guangxi, Guizhou, Hunan and Hubei etc... In addition to this, there is another type of magic knife in other China regions, for instance, in Guangxi, Guizhou, Hunan and Anhui. Here, the magic knife is a knife attached to a big iron ring at the end of the handle along with a number of small loose iron rings fitted to the big ring.

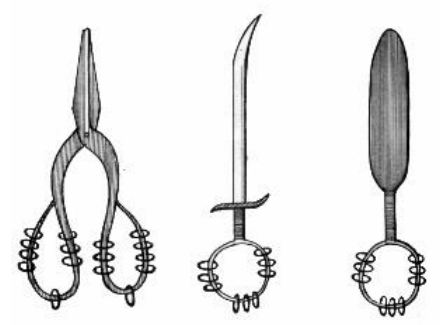

FIGURE 41: Magic knife in various shapes. (Drawing royalty-free open source, expired webpage).

There is a type of luan-bell knife mentioned in The Book of Songs, which is similar to magic knife in form and structure except that the former has bells and the latter has rings. The poem Bless people with a bumper harvest each year, and a good health and long life is illustrative of its connection with religious cult. There are certain similarities between Chinese luan-bell knife

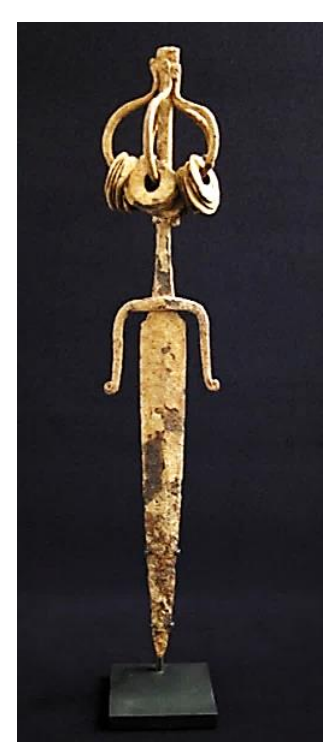
and Egyptian sistrum in form, structure and function. Thus, a question remains as to whether it is a coincidence or mutual influence. When it comes to time, the luan-bell knife appeared later than sistrum. Could it be that the luan-bell knife was created with the inspiration from sistrum? According to the claim "Chinese civilization originated from ancient Egyptian" (Luo Ling-jie, 2012; Liu Guang-bao, 2018), we might find out the answer to this question.

As interpreted by Xiao Mei, shaking bells upwards implies inviting gods or ancestors while vibrating rings (or discs of iron or gourd) downwards implies warding off or exorcising evil spirits. In the Zhou Period in Chinese history, the luan-bell knife with only bells had only one function and nowadays the magic knife with both bells and rings has both functions.

FIGURE 42: Magic knife with rings, probably of the Iu Mien (Yao) shamans living in China. (Photography by courtesy of Zena Kruzick, accessible via http://zenakruzick.com/asian-tribalart/asian_tribal_art_dagger_yao- 2605 details.htm, last accessed 1 May, 2020). 


\section{SaChI, Sinh Tien, PeACE-DRUm}

The Sachi is common in Zhejiang and Fujian Prvoinces of China, of which the first syllable sa sounds quite similar to the pronunciation of a sistrum, and has similar function in culture to $x i$ stick rattle and sabayi. Beggars would use it when singing something to beg for alms.

As described in An Illustrated Encyclopedia of Chinese Music History [Liu \& Quan, 1988], it is a thin bamboo pole with some holes in it and a number of loose copper coins fitted into these holes by fixing them with an iron rod.
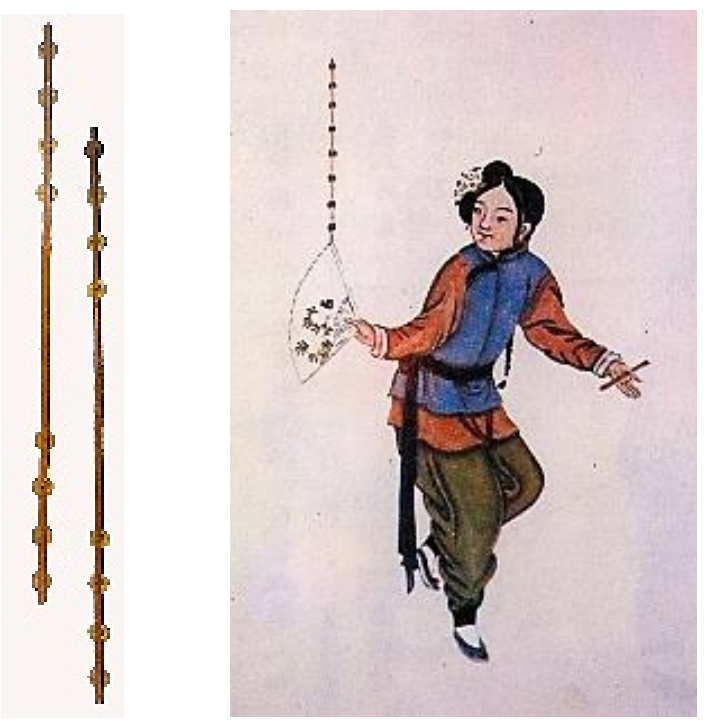

FIGURES 43-44: Sachi in the first picture and in the second, a girl plays a dalianxiang, the other shape of sachi (both depictions open access, expired website).

\section{Records on Music in 'The Draft History of the Qing Dynasty'}

Sinh tien (in Vietnamese) is a musical instrument consisting of three main parts often used by beggars in the Chinese context. The three parts are slabs of sandalwood, to one of which fitted are several copper coins. The back of the second part is serrated and the third has a jagged edge. The player holds the first two slabs with the left hand, clapping them against one another. Consequently, the coins create a rattling sound. Simultaneously, with the right hand, the musician pulls the third part up and down using its jagged edge to scrape the back of the second part with the aim at creating a scraping sound. This instrument is widely described in Vietnamese (Tran Van Khe, 1959) and other literature (Jähnichen, 2019).

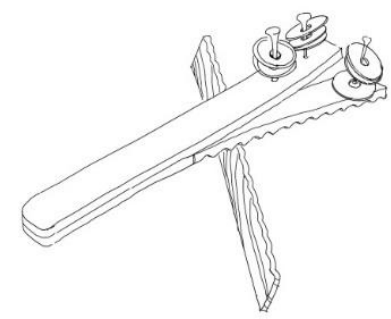

FIGURE 45: Sinh tien is a combined idiophone with rattle elements and scraping surface. It is used as accompaniment to songs performed by beggars in the Chinese context and in Central Vietnamese music traditions. (Drawing by courtesy of Wang Lei).

The taiping $g u$ (a peace drum) is an iron hoop covered with leather. A wooden handle with a big ring is fixed on its end that may contain further smaller metal rings. Since its form, structure 
and religious function are concerned, the peace drum seems to be a secularized drum of shamans, yet there is no definite proof for it.
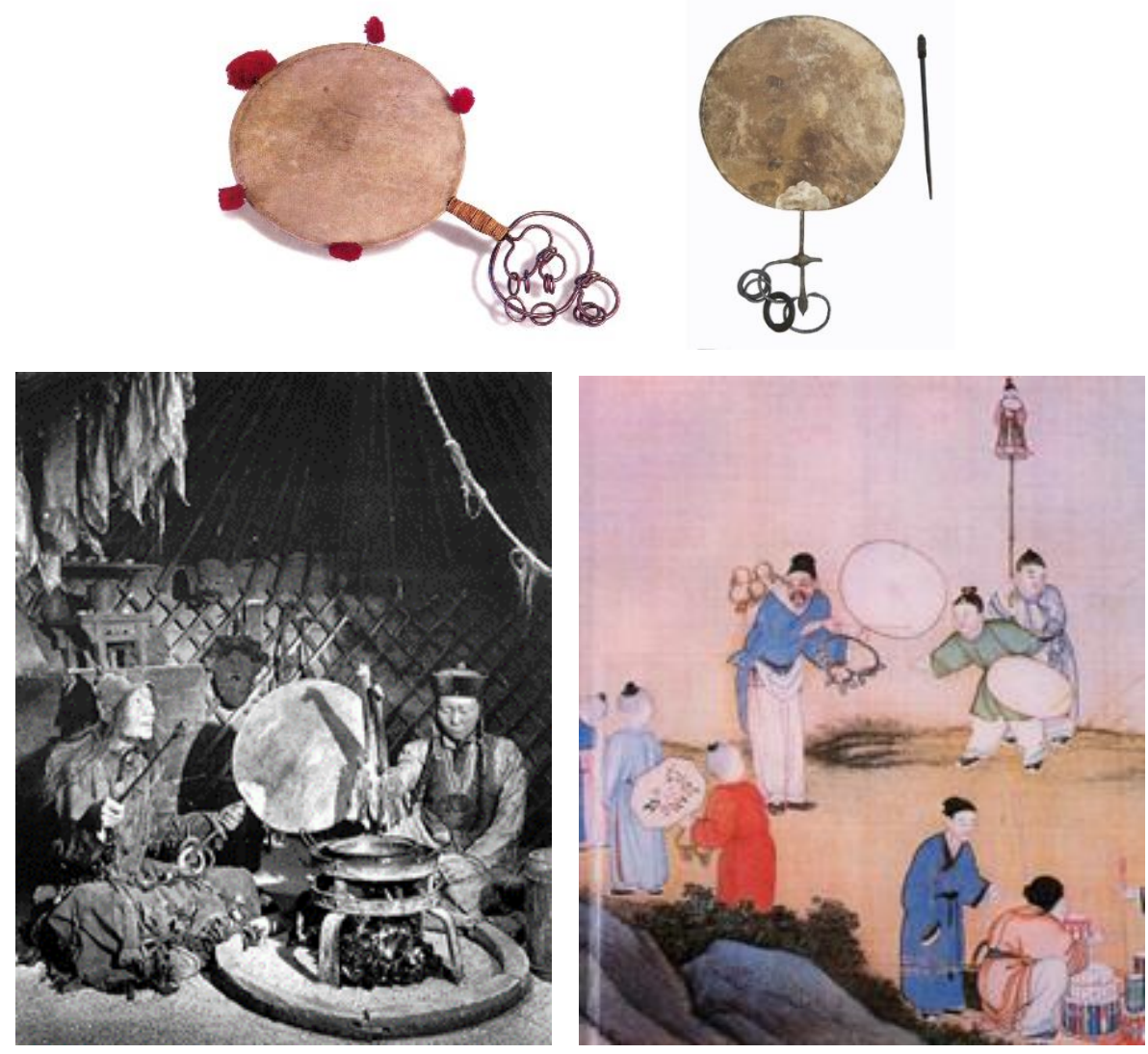

FIGURE 46: A taiping gu (according to the Chinese Musical Instrument Atlas, 1987: 141); FIGURE 47: The Mongolian shaman drum, exhibited in Denmark National Museum, Copenhagen (Photography by courtesy of Liu Guiteng, July 2014); FIGURE 48: The shamans are in divination using the shaman drum. Exhibited as 'Shamaner og andermanere/p.3' (Photography by courtesy of Liu Guiteng, July 2014); FIGURE 49: A Peaceful Spring Market (Picture by courtesy of Ding Guanpeng, 1988).

There is a popular rhyme coming to my mind:

Iron rings ringing and drums pounding,

Crowds dancing as the old year leaving.

Air of peace and happiness everywhere,

Kangqu and Jirang praising the same thing.

This is a ballad dating back into the Qing Dynasty, which is up to present days a true and vivid portrayal of the scene in the second picture. Kangqu and Jirang are folk songs praising the sagacious monarch appointing talents to important positions and praying for a great harmony in the world of peace and safety.

\section{SOME BRIEF ANALYSES}

\section{Etymology/ Pronunciation of NAmes}

The first syllables sound respectively similar to $s i, x i$, $s a$ or $s e$, which appear to be connected to the pronunciation of the sistrum that had been found in Egypt. The named syllables are believed to be onomatopoeia of the rattling sound when snakes are seeking a spouse ${ }^{4}$. In Darwin's book

\footnotetext{
4 Snakes cannot hear acoustically. The rattling of their dried-out tail ends is rather to warn animals that can hear
} them than calling for a mate that definitely cannot hear the rattling sound. Although snakes may have a very 
titled "The Descent of Man, and Selection in Relation to Sex", rattle snakes were mentioned. He said that when two rattle snakes meet, they will "entwine into a ball with their heads standing up straight, creating jiajia- sound intermittently ... then begin copulating." (Darwin 1983 [1871]: 544). It can be concluded that human beings may associate this specific sound with copulating behaviour. The given description above may remind to the copulating of Fuxi and Nuwa, the ancestor gods in some Chinese myths, of which an image of copulating of Fuxi and Nuwa is provided in a stone relief of the Han Dynasty inside the Wu Liang Shrine. It was depicted by Zhu Xilu and printed in Shandong Fine Arts Press, 1986, on page 50.

In Xiao Mei's (2013) “A Study of Spiritual Music in the Context of Institutionalized Sound [响 器制度下的 “巫乐” 研究]”, where the role of percussive music as part of the institutionalized spirituality is investigated, the sala-hoop, used by the sangpa of the Naxis in the Lijiang area, is the onomatopoeia of the sound its iron discs create when they are shaken. And the xicer in her article, the other name of a ring knife of the $Y i$ s, is the onomatopoeia of the rustling its iron discs create when shaken, which is even more similar to the pronunciation of the Egyptian sistrum.

\section{Form, Structure, ANd SOUnd Production}

Each of these instruments contains strings of metal rings, bells, discs, gourd discs or copper coins, which create a rapid succession of cracking and complex sound. This is the property of many simple rattles, musical instruments, and ritual tools used in religious services.

\section{Cultural Function}

The instruments, which can simulate frogs croaking during a tropical rainy season, are connected to praying for rain, and those that can simulate fertility.

In the world, Gods, for instance, Isis, the Herbalist Buddha or the King of Jizo as well as sorcerers such as shamans, witches, ashiqs or bakshis, would use a sistrum, a stick rattle or a similar instrument while praying for children, for rainmaking, for peace and safety. Furthermore, these instruments are sounded for curing diseases and for longevity. They are also played to ward off evil spirits and plagues, and to frighten away poisonous insects. All these rituals belong to the specific world views that are attached to the importance of reproduction in early times of humankind.

\section{RELIGIOUS THEMES}

Wherever they are, in Egypt, Greece, India or China, they all involve fertility, death, reincarnation, eternal life through death, and the function of triggering trance, in which people seem to feel themselves connected with heaven and earth, deities or ancestors.

Those in charge of life and death are respectively Isis and Osiris (king of hell) in an ancient Egyptian myth, Dionysus (Bacchus) and Demeter (queen of hell) in an ancient Greek myth, and the Herbalist Buddha (Bhaisajyaguru) and the King of Jizo (Ksitigarbha) in Indian Buddhism. Shiva in Hinduism takes charge of both.

The ancient Egyptian sistrum and its connotations in religious and magical events are the model of stick rattles, among them the xizhàng. Perhaps, that is why scholars like Katharine Schlesinger, who annotated Stein's Serindia, and some oriental Buddhists called the xízhàng just sistrum directly and put them in the same category.

With Buddhism entering China, the stick rattle xízhàng and its connotation in religious and

well-trained sense of feeling vibrations (Knight, 2012), this interpretation is based on a mistake found in very early biologist writings, also of Charles Darwin (1871/1983) himself. 
magical rituals have spread widely into the Western regions and the hinterland of China as well, from which again derived many other rattle types, musical instruments, and ritual tools in sacred services.

\section{Additionally: The Bell Stick}

There are also the remains of the xízhàng stick rattle in the West, which can be seen in the socalled bell stick, also known as Turkish Crescent or Chinese Pavilion. It is a type of stick rattle, yet it is not exactly the same as described above. The former has bells jingling when shaken, whereas the latter has iron rings that rustle when stroked. As far as the form and structure in general are concerned, there should be a certain relationship between the bell and the stick rattles with regard to their originstick rattle.

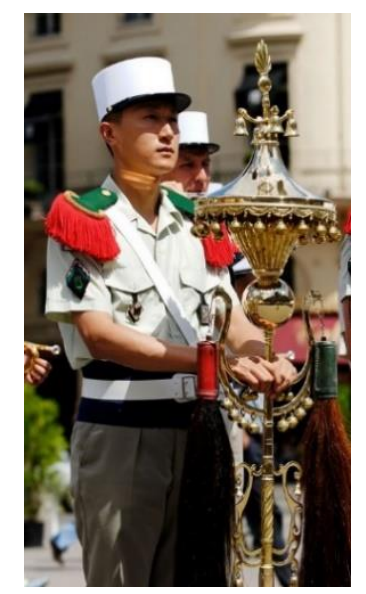

FIGURE 50: A bell stick, also called Turkish crescent or Chinese pavilion. Soldier of the Music of the French Foreign Legion holding the "Jingling Johnny" during the celebrations of Bastille Day 2008 in Paris. (Photography by courtesy of Nguyen Marie-Lan).

The Turkish Crescent is supposed to be a stick rattle with an ornamental Turkish Crescent, the symbol of Islamic civilization, in the Islamic areas whereas the Chinese pavilion, generally having a conical hat at the top, obviously indicates its relation to the Chinese Buddhist stick rattle.

The bell stick was known in West Asia and Europe from the $16^{\text {th }}$ century onwards and it was used mainly in military orchestras. As such, it became an important instrument in the Janissary band and then the British military bands adopted it in the late $18^{\text {th }}$ century.

Berlioz used this instrument in his Funeral and Triumphal Symphony (OP.15). His 'dream' ensemble of 467 instrumentalists included four pavilions chinois among the 53 percussion instruments.

(This paper was translated by Yi Kai and Gisa Jähnichen from a revised and partly extended and corrected version of Long Fei's Sistrum $\bullet X i$-stick $•$ Sabay, initially written in Chinese and originally published in the Academic Journal Ritual Soundscapes, December, 2013: 28-56.)

\section{REFERENCES}

Bernal, Martin. 1987, 1991, and 2006. Black Athena: The Afroasiatic Roots of Classical Civilization. New Brunswick: Ruttgers University Press.

Blade, James. 2005 (first published in 1970). Percussion Instruments and their History. Revised Edition. Westport: The Bold Strummer.

Chen Cheng and Li Siang. 1991 [Ming Dynasty]. Series of Historical Records of Chinese and Foreign Transportation [西域行程记西域番国志咸宾录一一中外交通史籍从刊]. Beijing: Zhonghua Book Company.

Darwin, Charles. 1871. The Descent of Man, and Selection in Relation to Sex. 1 (1st ed. in Chinese translation from 1983). London: John Murray.

Ding Fubao. 1987. Cultural Relics. Beijing: Beijing Press,1362.

Great Dictionary of Chinese Musical Instruments. 2002. Beijing: Yue Sheng.

Halén, Harry and Bent Lerbæk Pedersen. 1993. C.G. Mannerheim's Chinese Pantheon. Helsinki: FinnoUgrian Society.

Heise, Birgit. 2002. Membranophone und Idiophone. Europäische Schlag- und Friktionsinstrumente. Musikinstrumenten-Museum der Universität Leipzig. Katalog, 231. 
Hornbostel, Erich Moritz von and Curt Sachs. 1914. Systematik der Musikinstrumente: Ein Versuch. Zeitschrift für Ethnologie, 46 (4-5): 553-90.

Jähnichen, Gisa. 2019. "Idiophones: Scraped Instruments". The SAGE International Encyclopedia of Music and Culture. Edited by Janet Sturman. London: SAGE Publishing, 1135-1138.

Kebede, Ashenafi. 1982. Roots of Black Music: The Vocal, Instrumental, and Dance Heritage of Africa and Black America. Tallahassee: Ethius.

Kishibe Shigeo 岸邊成雄. 1973. Tangdai yinyue shi de yanjiu 唐代音樂史的研究. Taipei: Taiwan Zhonghua Publishing House [Japanese original: Tōdai ongaku no rekishiteki kenkyū. Gakusei hen. 唐代音樂の歷史的研究. 樂制篇. 1960-1961. Tōkyō: Tōkyō daigaku.].

Knight, Kathryn. 2012. Snakes Hear Through Skull Vibration. Journal of Experimental Biology, 215: ii. DOI: $10.1242 /$ jeb.069104.

Long Fei 陇菲. 1991. Materials of Chinese Music History in Dunhuang Frescoes. Lanzhou: Dunhuang Literature and Art Press, 446-450.

Midgley Ruth, ed. 1976. Musical Instruments of the World. The First and Only Comprehensive Illustrated Encyclopedia of Its Kind. New York \& London: Paddington Press.

Powne, Michael. 1968. Ethiopian Music an Introduction: A Survey of Ecclesiastical and Secular Ethiopian Music and Instruments, Oxford University Press. London

Sachs, Curt. 2006. The History of Musical Instruments. Unabridged re-publication of the work originally published in 1914. New York Dover Publications.

Schlesinger, Katharine. 1921. Notes on Musical Instruments Represented in the Stein Collection. Aurel

Stein, Serindra, Detailed Report of Explorations in Central Asia and Westernmost China, Oxford, I Z I 1(4): 67-69.

Zhu Xilu. 1986. Photography of Fuxi and Nuwa Copulating, Stone Relief of the Han Dynasty inside the Wu Liang Shrine. Shandong: Shandong Fine Arts Press, 50.

Subhi Anwar Rashid. 1984. Mesopotamien. Musikgeschichte in Bildern, Bd. II, Musik des Altertums/Lieferung 2. Leipzig: Deutscher Verlag für Musik.

Timkehet Teffera. 2016. The Ethiopian Sistrum Tsenatsil [ $\dot{\theta} \zeta \dot{\hat{\theta}} \mathrm{A}]$. Unpublished ms. Accessible via https://www.academia.edu/25634894/Timkehet_Teffera_2016_._The_Ethiopian_Sistrum_Tsen atsil_\%E1\%8D\%85\%E1\%8A\%93\%E1\%8D\%85\%E1\%88\%8D_.

Xiao Mei, Kong Chongjing, and Zhang Zhenrui, 2019. Shaanbei Pipa Shuoshu (Pipa Storytelling of Shaanbei) from the Perspective of Inner Asia. Plucked Lutes of the Silk Road. Edited by Lawrence J. Witzleben and Xiao Mei. Shanghai: Shanghai Conservatory of Music Press, 22-48.

Xiao Mei. 2013. A Study of Spiritual Music in the Context of Institutionalized Sound [响器制度下的 “巫乐”研究]. National Arts, 2: 28-37.

Yates, James. 1875. Sistrum. A Dictionary of Greek and Roman Antiquities William Smith, D.C.L., LL.D. John Murray, London. 1875: 1046 (Online accessible: http://penelope.uchicago. edu/Thayer/E/Roman /Texts/secondary/SMIGRA*/Sistrum.html; last retrieved 25 May, 2016)

Yuan Bingchang and Mao Jizeng. 1986. Zhongguo Shaoshu Minzu Yueqi Zhi [The Musical Instruments of the Chinese National Minorities: A Dictionary]. Beijing: Xin Shijie Chuban She [The New World Press].

Zhongguo Yinyue Cidian. 1984. [Dictionary of Chinese Music]. Beijing: Folk Music Publishing.

Zhongguo yinyue tuzhi [Chinese Musical Instrument Atlas]. 1987. Beijing: Qinggongya Publishing.

Zhōngwài jiāotōng shijí cóngkān běn. 2000. \{Chen Cheng and Li Siang. N.d. (Ming Dynasty). Series of Historical Records of Chinese and Foreign Transportation. Proofread and annotated by Zhou Liankuan \}. Beijing: Zhonghua Book Company. 